\title{
POSITIVISME LOGIS DALAM “LANGUAGE, TRUTH, AND LOGIC" KARYA ALFRED JULES AYER: SEBUAH PANDANGAN KRITIS
}

\author{
Fiandy Mauliansyah \\ Program Studi Ilmu Komunikasi \\ FISIP-Universitas Teuku Umar \\ Email: Fiandymauliansyah@gmail.com
}

\begin{abstract}
The essence of science in the body of logical positivism is based on the basis of the development of the exact sciences, so that the sciences developed are not always in line with the development of society. The objectivity that is concerned with the sciences is precisely molded in terms of the unfolding of the sciences, so it is absolute to use subjectivism which in principle will reflect its objectivity. Scientific truths are measured positivistically, in the true sense and the real must be concrete, logical, accurate and rewarding. The effect behind it is that the abstract and qualitative dimensions of life are neglected and apart from observation. No doubt if the criticism and correction of positivism waged because of its naturalistic and diterministik. Humans are seen only as dependent and not as independent variables.
\end{abstract}

Keywords: Logical Positivism, Languange, Truth, and Logic

\section{Pendahuluan}

Kehadiran era modern saat ini ditandai dengan dinamisasi di berbagai aspek kehidupan manusia. Dari yang konkrit seperti, perkembangan ilmu pengetahuan dan teknologi dengan segala bentuknya, sampai pada yang abstrak seperti nilai-nilai normatif. Bidang ilmu pengetahuan cenderung diwarnai nilai-nilai positif, terbukti dengan penemuan teori-teori baru yang dirasakan lebih bermanfaat untuk mendukung upaya manusia dalam menguak tabir kemisterian alam. Sementara pada aspek normatif nilai-nilai yang ada dan sudah lama dipertahankan dalam masyarakat termasuk norma agama, perkembangannya lebih diwarnai oleh nilai-nilai negatif.

Kedua bentuk perubahan ini berkorelasi secara causalistik, dimana nilai-nilai negatif yang tampak pada perubahan normatif merupakan akibat dari hasil proses dinamisasi ilmu pengetahuan dan teknologi. Hal ini menjadi dilematik ketika kehadiran ilmu pengetahuan dirasakan sangat dibutuhkan untuk lebih mempermudah mekanisme kehidupan manusia, sementara kehadirannya melahirkan dampak yang justru dapat merusak mekanisme itu sendiri. Hal ini melatarbelakangi munculnya berbagai paham (isme-isme) yang memiliki karakteristik pemikiran yang berbedabeda. Diantaranya muncul suatu aliran yang menekankan pada kebenaran yang sifatnya positivistik.

Positivisme sekarang telah menjadi istilah umum untuk posisi filosofis yang menekankan aspek aspek faktual pengetahuan, khususnya pengetahuan ilmiah dan menolak nilai kognitif dari studi filosofis atau metafisis. Mereka menyatakan "salah" dan tidak bermakna semua konsep dan proposisi dari filsafat tradisional tentang "ada", substansi, sebab akibat dan segala yang tidak dapat dipecahkan atau diverifikasi oleh pengetahuan yan berkaitan dengan suatu tingkat yang tinggi dari alam abstrak. Pemikiran positivisme ini memberikan dasar pijakan bagi paham filsafat analitik terutama kelompok Wina (viena circle), yang menamakan dirinya sebagai positivisme 
logis.

Seluruh pandangan positivisme diangkat oleh positivisme logis, hanya perbedaannya positivisme logis lebih menekankan pada analisa bahasa dan prinsip verifikasi. Positivisme logis merupakan sebuah model epistemologi era kontemporer yang di dalam langkah-langkah progresinya menempuh jalan melalui observasi, eksperimentasi dan komparasi sebagaimana diterapkan dalam penelitian ilmu alam, juga memakai model penelitian dengan menggunakan presisi verifiabilitas, konfirmasi dan eksperimentasi dengan derajat optimal, dengan maksud agar sejauh mungkin dapat melakukan prediksi dengan derajat ketetapan yang optimal pula.

Kebenaran ilmiah diukur secara positivistik, dalam arti yang benar dan yang nyata haruslah konkret, logis, akurat dan memberi kemanfaatan. Akibat dibalik itu adalah bahwa dimensi-dimensi kehidupan yang abstrak dan kualitatif menjadi terabaikan dan terlepas dari pengamatan. Tak ayal kalau kritik dan koreksi terhadap positivisme dilancarkan karena sifatnya yang naturalistik dan diterministik. Manusia dipandang hanya sebagai dependent dan bukan sebagai independent variabel.

Positivisme merupakan perkembangan lanjut dari aliran empirisme. Seperti yang kita ketahui bahwa empirisme telah menjadi sumber filosofis bagi positivisme, terutama pada masalah pandangan objektiv mereka terhadap ilmu pengetahuan. Empirisme yang didukung filsuf Inggris ini (Locke, Hume, Berkeley) meyakini bahwa realitas adalah segala sesuatu yang bisa dijangkau oleh indera. Lebih dari itu, seiring dengan perkembangan zaman, positivisme mengembangkan paham empiris ini lebih ekstrim lagi, yakni menyatakan bahwa puncak pengetahuan manusia adalah ilmu-ilmu positif atau sains yang berangkat dari fakta-fakta empiris.

Dalam perkembangannya, pada abad ke-20 M muncullah sebuah aliran filsafat ilmu pengetahuan yakni positivisme logis, dimana positivisme logis (neopositivisme) ini berkembang di Lingkungan Wina, Austria. Diantara tokoh positivisme logis yang akan penulis bahas pada paper ini adalah Alfred Jules Ayer. Penulis rasa perlu untuk mengemas pemikiran A.J Ayer dalam makalah ini karena beliaulah yang berperan besar dalam perkembangan positivisme logis. A.J. Ayer-lah yang memperkenalkan positivisme logis yang berkembang di Lingkungan Wina untuk dikenalkan di negara-negara lain yang berbahasa Inggris.

\section{Historisitas Positivisme Logis}

Munculnya Neo-Positivisme atau Positivisme Logis, berhubungan erat dengan Lingkungan Wina, yakni suatu kelompok yang terdiri dari sarjana-sarjana Ilmu Pasti, Ilmu Alam, Ahli Matematika, Logika dan Sains. Gerakan filsafat ini dirintis oleh Moritz Schlik (1882-1936) pada tahun 1924 yang berpusat di Wina, suatu kota sekaligus sebagai pusat kelompok yang terkenal dengan nama Vienna Circle atau disebut dengan Mazhab Wina (Kring Wina). Anggotanya antara lain: Kurt Goedel, Hans Hahn, Karl Menger (ketiga-tiganya ahli matematika), Victor Craft seorang filofos, Rudolf Carnap seorang ahli matematika dan fisika serta beberapa mahasiswa antara lain: Friedrich Wismann Herbert Feigl (Bertens: 1983). Aliran ini sangat dipengaruhi oleh pemikiran Ludwig Wittgenstein, sekalipun Wittgenstein tidak ikut aktif dalam kelompok tersebut. Pendirian filosofis kelompok lingkungan Wina ini sangat diwarnai oleh ilmuilmu pengetahuan positif, terutama pemikiran Auguste Comte tentang kritiknya atas agama dan metafisika sebagai sumber kebenaran (Patterson; 1971) dan dipengaruhi pula oleh tradisi empirisme David Hume dan analisis logis Russell.

Verhaark menegaskan bahwa adanya pengaruh tiga arah dalam tubuh positivisme logis, yakni: pertama, dari empirisempirisme dan positivisme, terutama Hume, Mill dan Mach. Kedua, dari metodelogi empiris yang dikembangkan oleh para ilmuwan semenjak abad ke-19, misalnya Helmholrz, Mach, Poincare, Einstein dan lain-lain. Ketiga, perkembangan logika simbolik yang dikembangkan terutama oleh Frege Whithead, Russell dan Wittgenstein (Wittgenstein; 1997). Salah satu tujuan dari gerakan ini adalah ingin memperbaharui positivisme klasik Auguste Comte, 
sekaligus memperbaiki kekurangan-kekurangannya. Dari sekian banyak pengikut aliran ini, Ayer dipandang paling memiliki momentum dalam menyatakan gagasannya. Lambat laut mengalami serangkaian modifikasi sebagai jalan menutupi kelemahan-kelemahan yang ada. Verifikasi sebagai kriteria keberartian, secara berturut-turut dimodifikasi ke dalam verifikasi prinsip, komfirmabilitas yang akhirnya desakan bahwa evidensi empiris harus memainkan suatu peranan yang berarti dalam penerimaan suatu pernyataan ilmiah.

Pada saat yang sama basis faktual diperluas, dari pencerapan dan kelaporan serta pengamatan ke bahasa empiris. Positivisme dewasa ini pembicaraannya berkenaan dengan 3 (tiga) komponen bahasa, yakni bahasa teoritis, bahasa observasional dan kaidah-kaidah korespondensi yang mengaitkan keduanya. Tekanan positivistik menggaris bawahi penegasannya bahwa hanya bahasa observasional yang menyatakan informasi faktual, sementara pernyataanpernyataan dalam bahasa teoritis tidak mempunyai arti faktual sampai pernyataan-pernyataan itu diterjemahkan ke dalam bahasa observasional dengan kaidah-kaidah korespondensi. Ayer mencoba mengintrodusir pemikiran positivisme logis yang berkembang di lingkungan Wina dan mensintesakan dengan metode yang dipakai oleh Moore dan Russell. Kelihatannya Ayer memiliki corak tersendiri dalam menciptakan klarifikasi dan ketelitian dalam bidang filsafat. Ia juga meneruskan tradisi empiris Inggris terutama Hume dan titik tekannya pada analisis logis versi Bertrand Russell.

\section{Corak Pemikiran Positivisme Ayer}

Alfred Jules Ayer (1910-...) sebagai salah seorang filsuf mengembangkan konsep filosofis positivisme logis secara lebih radikal. Ia pernah berkunjung pada Universitas di Wina dan sekembalinya ke Inggris ia diangkat sebagai dosen di Oxford dan merupakan salah seorang profesor logika di Universitas tersebut. Bukunya Language, Truth and Logic merupakan salah satu karya yang sangat dikagumi oleh peminat filsafat Inggris pada abad ke-20. Pendirian yang dikemukakan dalam buku ini agak radikal. Tulisan kedua Ayer yang dapat dianggap penting adalah The Problem of Knowledge (1956), yang di dalamnya berisikan problem-problem yang menyangkut skeptisisme filosofis. Buah karyanya yang lain adalah: The Foundation of Emperical Knowledge (1940); The Origins of Pragmatism (1968); Russell and Moore, The Analytical Heritage (1971); Russell (1972); Probability and Evidence (1972); The Central Problems of Philosophy (1973) (Bertens; 1983). Sebenarnya pandangan Ayer dalam bukunya Language, Truth and Logic, bukan sesuatu yang baru dalam filsafat abad ke-20. Sebagian isinya sejalan dengan apa yang dikemukakan oleh Lingkungan Wina.

Sebelumnya telah dijelaskan bahwa untuk beberapa waktu Ayer menetap di Wina. Tujuan kunjungannya justru ingin berkenalan secara langsung dengan pemikiran para anggota Lingkungan Wina dan melalui bukunya ia mengintrodusir cara berfikir positivisme logis di Inggris. Ajarannya disambut hangat dan dijadikan sebagai suatu pandangan filosofis yang penting. Pendekatan Ayer dianggap cocok dan sesuai dengan usaha yang telah dilakukan sebelumnya oleh Moore dan Russell untuk menciptakan kejelasan dan ketelitian di bidang filsafat. Positivisme logis Ayer sebenarnya merupakan percobaan untuk mengaitkan analisis logis Russell dan tradisi empiristis Inggris, terutama Hume. Dan Ayer yakin bahwa apa yang dicarinya sudah dihasilkan dengan baik oleh Lingkungan Wina. Positivisme logis juga merupakan aliran yang membatasi pikiran pada segala hal yang dapat dibuktikan dengan pengamatan atau analisis definisi dan relasi antara istilah-istilah.

Menurut positivisme logis, filsfat ilmu murni mungkin hanya merupakan analisis logis tentang bahasa ilmu. Fungsi analisis ini di satu pihak mengurangi metafisika (filsafat dalam arti tradisional) dan di lain pihak meneliti struktur logis pengetahuan ilmiah dan bertujuan untuk menentukan isi konsep-konsep dan pernyataan ilmiah yang diferifikasi secara empiris. Sebagaimana dijelaskan bahwa kelompok lingkungan Wina di satu pihak menaruh antusiasme 
besar bagi ilmu pengetahuan dan matematika, di lain pihak mengambil sikap negatif terhadap metafisika. Yang penting bagi mereka menentukan bermakna atau tidaknya suatu ungkapan dalam filsafat dan ilmu pengetahuan, tidak mempersoalkan benar tidaknya suatu ungkapan, sehingga pada gilirannya mereka ingin mewujudkan "bagaimana dapat ditentukan suatu norma yang jelas yang dapat membedakan ungkapan-ungkapan yang bermakna dari ungkapan yang tidak bermakna". Untuk itulah kemudian mereka menentukan apa yang dikenal dengan "Prinsip Verifikasi".

Corak pemikiran positivisme logis ini, kelihatannya bertujuan membatasi penyelidikannya dengan menghindari diskusi panjang yang mereka pandang tidak ada buahnya. Menurutnya dengan metode baru yang diterapkan mereka, manusia akan terbebas dari perbincangan yang sia-sia, dimana keadaan ini telah diyakini para filsuf sejak berabad-abad, sehingga menghilangkan kekacauan-kekacauan dalam berfikir. Pemikiran-pemikiran filsafat pada zaman Yunani, dinilai oleh para aktivis positivisme logis ini telah memakan waktu lama dan telah banyak membuang-buang tenaga dengan mengesampingkan pembahasan ini dari kehidupan ini, sehingga manusia pada hakikatnya telah tertipu oleh jalan pikirannya sendiri.

Melalui tahap perkembangannya, positivisme logis memandang ahli filsafat dahulu menyelidiki tentang penyebab pertama, hakikat manusia, jiwa, keadilan dan lain-lain, kesemuanya tidak memberikan sumbangan yang berarti kepada manusia dalam memahami realitas kehidupan dan semua perbincangan tersebut tidak akan terlepas dari pembuktian inderawi. Pernyataan "Tuhan itu ada" atau "Tuhan itu tidak ada" tidak dapat dibuktikan secara empiris, maka omong kosong belaka, artinya tidak benar dan tidak pula dusta (Peursen; 1980).

Lebih lanjut, Ayer mengatakan bahwa theisme sangat kacau dan kalimat- kalimat tentang Tuhan tidak dapat diverifikasi (diuji kebenarannya) atau tidak dapat dikatakan salah (falsifikasi), maka berbicara tentang kepercayaan atau ketidakpercayaan, keyakinan atau ketidakyakinan secara logis tidaklah mungkin. Atheisme dan Theisme sama-sama tidak dapat dipahami dan tidak bermakna. Tidak ada alasan untuk menyangkal atau meragukan konsep tentang "Tuhan" (Amstrong; 1993). Komentar lainnya dapat dikemukakan dalam ungkapan Wittgenstein tentang metode menentukan kebenaran dalam filsafat, yakni "hanya mengatakan apa yang bisa dikatakan, sehingga diam adalah pilihan yang tepat dalam menghadapi hal-hal yang tidak dapat dibicarakan. Salah satunya adalah persoalan metafisika, karena tanda-tanda proposisi tidak akan terbukti dalam pembicaraan tersebut" (Paterson; 1976).

Melalui analisis bahasa, ia mengungkapkan bahwa masalah-masalah filosofis hanya dapat terpecahkan apabila kata-kata yang digunakan tidak mengandung kekaburan arti (vagueness), kemaknagandaan (ambiquity) dan ketidakterangan (in explisitness). Menurut positivisme logis, pengetahuan adalah kesan yang dirangsang oleh obyek kepada indera kita dan pengetahuan termasuk kebenaran tidak lain adalah respon indera terhadap rangsangan dari obyek tersebut.

\section{Prinsip Verifikasi}

Sebagaimana kita ketahui bahwa konsep-konsep dasar dari pemikiran positivisme logis sangat diwarnai oleh logika, matematika serta ilmu pengetahuan alam yang bersifat positif dan empiris, maka sudah dapat dipastikan bahwa analisis logis tentang pernyataan-pernyataan ilmiah maupun pernyataan filsafat sangat ditentukan oleh metode ilmu pengetahuan positif dan empiris tersebut. Dalam pengertian inilah maka positivisme logis mengembangkan prinsip verifikasi.

Di dalam bukunya, Ayer merumuskan prinsip verifikasi sebagai berikut:

"We say that a sentence is factually significant to any given person, if, and only if, he knows what observations would lead him, under certain conditions, to accept the propotition as being true, or reject it as being false. If, on the other hand the putative 
proposition is of such a character that assumption whatsoever concering the nature of his future experience, then, as far as he is concerned it is, if not a tautology, a mere pseudo-proposition. The sentence expressing it may be emotionally significant to him, but it is not literary significant" (Ayer, 1952 : 48).

Berdasarkan pernyataan Ayer di atas dapat dijelaskan bahwa pada hakikatnya prinsip verifikasi bermaksud untuk menentukan bermakna atau tidaknya suatu ungkapan dan bukan untuk menentukan suatu kriteria kebenarannya. Sebuah ungkapan kadangkala dapat benar dan kadangkala dapat juga salah, namun ungkapan tersebut tetap bermakna. Suatu ungkapan itu bermakna menurut Ayer, bilamana ungkapan tersebut merupakan pernyataan observasi yang menyangkut dengan realitas inderawi. Dengan kata lain bermakna apabila dilakukan dengan observasi atau verifikasi. Oleh karena itu, dalam hal ini membutuhkan fakta atau data empiris (Stumpf; 1982).

Memverifikasi berarti menguji, membuktikan secara empiris. Setiap ilmu pengetahuan dan filsafat senantiasa memiliki suatu pernyataan-pernyataan baik berupa aksioma, teori dan lainlain, dianggap memiliki makna apabila secara prinsip dapat diverifikasi berdasarkan pengalaman empiris. Prinsip verifikasi disini tidak mengharuskan menghasilkan suatu pernyataan yang mesti benar. Konsekuensinya setiap pernyataan atau proposisi yang secara prinsip tidak dapat diverifikasi maka pernyataan tersebut pada hakikatnya tidak bermakna.

Pernyataan-pernyataan metafisis menurut positivisme logis merupakan pernyataan yang tidak bermakna, karena pernyataan-pernyataan tersebut tidak dapat diverifikasi. Pernyataan seperti "realitas itu bersifat absolut" atau "realitas itu tidak absolut" kedua-duanya tidak mungkin diverifikasi, konsekuensi-konsekuensinya kedua-duanya merupakan pernyataan yang tidak bermakna. Pernyataan tersebut tidak memiliki kemungkinan untuk dilakukan pembuktian secara empiris. Dari pernyataan di atas memberi pemahaman, bahwa ungkapan-ungkapan metafisis baik yang membenarkan maupun yang menegasikan ungkapan tersebut, kesemuanya omong kosong, sebab tertutup kemungkinan untuk diverifikasi. Ini merupakan penolakan yang sangat radikal kaum positivisme logis terhadap metafisika.

Berbeda dengan tokoh-tokoh lingkungan Wina, Ayer menekankan dua bentuk verifikasi, yakni verifikasi dalam arti ketat (strong variable) dan verifikasi dalam arti lunak. Verifikasi dalam arti ketat memberi arti kebenaran suatu proposisi didukung oleh pengalaman secara meyakinkan. Sedangkan, verifikasi dalam arti lunak, suatu proposisi yang hanya mengandung kemungkinan bagi pengalaman atau pengalaman yang memungkinkan. Kaum positivisme logis menganggap bahwa sesuatu itu bermakna apabila dapat diuji kebenarannya. Pengujian ini dapat dilakukan dengan dua cara, yakni proposisi analitik (analisis logis) dan proposisi empirik.

Proposisi analitik, kebenaran atau ketidak benaran tidak didasarkan pada pengalaman, melainkan pada pengujian proposisi-proposisinya. Proposisi analitik yakni; pertama, proposisi yang benar melalui pembatasan, semata-mata berdasarkan susunan simbol-simbolnya, yang sering dijumpai dalam matematika. Kedua, proposisi yang tidak didasarkan pada pengalaman, melainkan pada "apriori" (pengetahuan yang diperoleh melalui refleksi logis). Ketiga, proposisi yang mengandung kepastian dan keniscayaan "tautologi" (suatu pernyataan yang secara logis mesti benar). Keempat, proposisi yang mengandung makna sejauh didasarkan pada penggunaan istilah yang pasti, maknanya terletak pada bahasa dan ungkapan verbal. Observasi empirik, proporsisi ini ini lebih mudah dipahami, karena ia dikaitkan langsung dengan pengalaman yang pasti atau yang mungkin. Menurut Ayer, "proporsisi empirik adalah seluruh hipotesa yang mengandung kemungkinan untuk disahkan atau ditolak (confirmated or discredited) dalam pengertian pengalaman yang sebenarnya" (Hudson; 1976).

Dapatlah dipahami bahwa proposisi empiris merupakan proposisi faktual yang harus dapat diverifikasi secara empiris, sedangkan proposisi analitik merupakan proposisi yang kebenarannya tidak memerlukan verifikasi secara empiris. Proposisi analitik meliputi proposisi 
logika dan matematika yang memiliki kebenaran secara pasti ( kebenaran bbersifat tautologis), sehingga tidak memerlukan verifikasi pengalaman empiris. Sudah barang tentu Ayer harus mengakui adanya batas-batas yang berlaku untuk prinsip verifikasi, tidaklah suatu ungkapan bahasa itu diverifikasi secara langsung, dapat pula melalui suatu kesaksian seseorang yang dapat dipercaya. Dalam masalah ini Ayer menerima kebenaran atas kesaksian tersebut, kalau tidak demikian maka semua ungkapan bahasa pada masa lampau akan menjadi tidak bermakna. Ini memberi makna bahwa prinsip verifikasi mendapat tempat bagi fakta-fakta sejarah.

Verifikasi tidak harus dilakukan secara keseluruhan melainkan cukup sebagian saja dan kebanyakan dalam bidang ilmu-ilmu alam dan fisika. Kelihatannya Ayer lebih hati-hati dalam menentukan berbagai macam prinsip verifikasi dibandingkan dengan pemikir lingkungan Wina. Keyakinan terhadap prinsip verifikasi ini memiliki konsekuensi bahwa ungkapan-ungkapan metafisis adalah nirarti. Reaksi Ayer justru

lebih radikal dibandingkan drngan para tokoh lainnya. Ungkapan bahasa seperti "Tuhan adalah pencipta segala sesuatu termasuk alam semesta", "setiap manusia harus berbuat baik terhadap sesamanya" dan ungkapan-ungkapan metafisis lainnya, pada hakikatnya sama sekali tidak mengungkapkan realitas empiris, sehingga menjadi tidak bermakna ( tidak dapat diuji secara analisis logis dan tidak dapat pula dilakukan observasi untuk membuktikan validitas pernyataan tersebut). "A statement wich is not relevant to any experience...... has no factual content".

Walaupun reaksi terhadap metafisika telah dilakukan oleh Russell dan Moore, namun karena konsepnya yang sangat radikal maka filsafat Ayer dikenal juga dengan suatu radikalisme atas filsafat Bertrand Russell. Akibatnya pemikiran Ayer mendapat respon yang sangat besar dikalangan filsuf, baik yang bernada dukungan maupun yang bernada menentang (kaum teolog), dan silang pendapat ini juga terjadi di kalangan mereka sendiri.

\section{Ktitik Terhadap Metafisika}

Penolakan Ayer khususnya dan positivisme logis pada umumnya terhadap pengetahuan yang tak terungkap (metafisis), sekaligus menggambarkan konsekuensi- konsekuensi tugas filsafat menurut kacamata mereka. Ayer menggabungkan pandangan Moore - yang bertitik tolak dari penggunaan bahasa sehari-hari, dengan pandangan atomisme logis - yang didasarkan pada kerangka bahasa logika. Analisa bahasa sehari-hari dalam pandangan Moore, digunakannya untuk mencegah atau menelanjangi sejumlah pandangan metafisika (Charlesworth; 1959). Menurut pandangan Ayer konsekuensi utama yang ditimbulkan oleh prinsip verifikasi - baik variabel dalam arti yang ketat maupun yang lunak - dan proposisi analitik yang mengungkapkan batasanbatasan bahasa merupakan penghapusan terhadap metafisika. Proposisi metafisika yang berusaha mengungkapkan "substansi, eksistensi, keabadian jiwa" dan hal-hal abstrak lainnya, tidak bermakna sama sekali.

Proposisi seperti itu tidak dapat dianalisa bukan hanya karena tidak dapat diverifikasi secara empirik, tetapi juga disebabkan bentuk-bentuk peristiwa yang seperti itu tidak relevan untuk dinyatakan benar atau salahnya. Sepertinya penolakan kaum positivisme logis terhadap problem metafisis mencerminkan pergeseran problem kebenaran menjadi problem meaning. Ini menunjukkan bahwa kaum positivisme logis tidak ingin memperdebatkan masalah kebenaran, tetapi mereka lebih menekankan makna suatu ungkapan. Ungkapan- ungkapan tentang Tuhan tidak dimaksudkan untuk membuktikan ada atau tidaknya Tuhan, melainkan mereka menganalisa apakah pernyataan tentang Tuhan itu mengandung makna atau tidak. Berdasarkan hal tersebut, Ayer mengatakan bahwa tugas filsafat yang paling utama dan mendasar adalah menyingkap dan menghapuskan kekacauan metafisika yang dianggap sebagai parasit dalam pemikiran ilmiah dan juga dalam pemikiran sehari-hari. Kelihatannya prinsip filsafat dalam pandangan Ayer hanya bersifat kritik.

Kritik-kritik yang dilancarkan oleh filsafat itu memang bermanfaat untuk mengantarkan 
kita ke gerbang pengetahuan ilmiah, namun bukan berarti filsafat merupakan "Super Sciences", sebab tugas filsafat bukan menetapkan pengandaian- pengandaian bagi ilmu pengetahuan. Filsafat tidak bertugas positif sebagaimana ilmuilmu pengetahuan empiris. Fungsi filsafat melulu bersifat kritik. Kritik-kritik tersebut diarahkan pada ungkapan-ungkapan metafisik dan segala bentuk penafsiran metafisik yang dapat menjerumuskan kepada pernyataan-pernyataan yang tidak bermakna.

Titik tolak Ayer dalam menghapuskan metafisika, disamping menggunakan prinsip verifikasi, juga didasarkan pada gagasan Russell tentang aturan-aturan tata bahasa terhadap keniscayaan-keniscayaan logik. Sebagai contoh Ayer menunjukkan kasus yang umum terjadi dalam bahasa Inggris, yakni disaat kita menggambarkan sesuatu melalui penggunaan bentuk tata bahasa dari subjek ke predikat, di situ kita cenderung menganggap bahwa keharusan untuk membuat suatu perbedaan logik antara sesuatu yang digambarkan itu sendiri dengan sifat-sifat pengertiannya.

Pernyataan-pernyataan metafisis menurut positivisme logis merupakan pernyataan yang tidak bermakna, karena pernyataan-pernyataan tersebut tidak dapat diverifikasi. Pernyataan seperti "realitas itu bersifat absolut" atau "realitas itu tidak absolut"; kedua-duanya tidak mungkin diverifikasi, konsekuensinya kedua-duanya merupakan pernyataan yang tidak bermakna. Pernyataan tersebut tidak memiliki kemungkinan untuk dilakukan pembuktian secara empiris. Dari pernyataan di atas memberi pemahaman, bahwa ungkapan-ungkapan metafisis baik yang membenarkan maupun yang menegasikan ungkapan tersebut, kesemuanya omong kosong, sebab tertutup kemungkinan untuk diverifikasi. Ini merupakan penolakan yang sangat radikal kaum positivisme logis terhadap metafisika.

Melalui jalan pikiran Ayer, kita dapat memahami dengan jelas apa sebenarnya tujuan utama yang diinginkannya bersama-sama tokoh-tokoh positivisme logis lainnya. Mereka membentuk kembali bahasa sehari-hari menjadi bahasa yang dibatasi penggunaannya. Melalui teknik analisa bahasa dirumuskan pembatasan-pembatasan yang bersifat operasional. Selain itu mereka mengarahkan filsafat sebagai pendamping ilmu pengetahuan, dalam artian tujuan analisa filsafat adalah mengantar kita ke arah pandangan positivistik mengenai dunia.

Filsafat harus berkembang ke arah logika ilmiah, yakni kegiatan yang memperlihatkan pertalian logis dari hipotesa-hipotesa dan pembatasan simbol-simbol yang terdapat di dalamnya. Dengan demikian jelaslah bahwa alasan utama penghapusan metafisika oleh kaum positivisme logis ini, bukan hanya ungkapan- ungkapan metafisis tidak dapat diverifikasikan secara empirik, bukan pula sekedar tidak dapat dikategorikan sebagai proposisi-proposisi analitik. Tetapi yang jauh lebih penting dari kedua hal ini adalah kaum positivisme logis ini menjadikan filsafat sebagai pendamping utama atau pengantar ke arah bidang ilmiah dalam rangka menyusun pandangan yang positivistik tentang dunia.

Untuk mencapai taraf ini menurut positivisme logis, syarat utamanya adalah menyingkirkan persoalan-persoalan semu (pseudo problems) yang ditimbulkan para ahli metafisika. Menurut Ayer, alasan menentang metafisika itu bukan lantaran sang ahli metafisika itu mencoba menggunakan pengertian dalam suatu bidang yang tidak dapat mendatangkan faedah apapun, melainkan lantaran sang ahli metafisika itu mengajukan kalimat-kalimat yang gagal atau tidak memenuhi syarat untuk dikatakan sebagai kalimat yang benar-benar mengandung makna secara harfiah.

Menjadi jelaslah kepada kita bahwa penolakan Ayer tentang metafisika khususnya dan positivisme logis pada umumnya, lebih didasarkan pada kriteria- kriteria logis yang tidak dimiliki ungkapan-ungkapan metafisika. Penerapan prinsip verifikasi untuk menguji apakah suatu pernyataan bermakna atau tidak, diterima sebagai suatu cara yang paling tepat dan akurat untuk menggambarkan data faktual dan menghapuskan metafisika dalam bidang filsafat. 


\section{Evaluasi Kritis}

Banyak hal yang dengan spontan menjadi keyakinan manusia dan tidak dapat dipertanggung-jawabkan, inilah yang disebut Hume sebagai kepercayaan- kepercayaan. Demikian juga alasan teologis yang menjelaskan tentang tujuan segala sesuatu diciptakan oleh sang pencipta, menghendaki adanya tujuan akhir. Semua itu tidaklah berarti bagi Hume. Pandangan para filsuf dan ilmuan zaman pencerahan menunjukkan adanya pandangan dunia Barat cenderung berantakan manakala kemajuan-kemajuan dalam bidang ilmu pengetahuan dan teknologi tidak terbendung lagi.

Terlihat bahwa ada pemikiran yang mengubah Personal God ke Impersonal God karena pengaruh perkembangan ilmu pengetahuan. Ilmu seharusnya mendekatkan manusia dengan Tuhannya, bukannya menjauhkan dari-Nya. Maka dari itu perlu digaris-bawahi bahwa masalah ilmu yang scientific knowledge, kadang bersitegang dengan persoalan ketuhanan karena keduanya berbeda, perbedaannya tidaklah kontradiktif, tetapi berbeda secara kontrer. Jadi bagi penulis, Personal God merupakan pilihan, daripada Impersonal God, sehingga ilmu itu lebih mendekatkan manusia kepada penciptanya. Dunia filsafat menurut Russell, memang berada antara dua macam pengetahuan: teologi dan sains, dogma dan ilmu pengetahuan yang pasti. Berhubungan dengan teologi, filsafat cenderung melahirkan spekulasi, keragu-raguan dan sebaliknya, berhubungan dengan sains, filsafat menegaskan seruannya pada akal, human reason, bukan mengacu pada teks (dogma otoritas) (Russell; 1974). Hal ini menggambarkan perbedaan jelas antara periode modern dengan periode abad pertengahan, yaitu meningkatnya otoritas sains dan melemahnya otoritas gereja. Konsekuensinya sangat mempengaruhi pergeseran paradigma berpikir dan membentuk kecenderungan baru dalam pengembangan filsafat berikutnya. Penekanan pada pengalaman menunjukkan aspek empirisme yang kuat dalam tubuh positivisme logis. Oleh karena itu positivisme logis sering diindentikkan dengan empiris logis. Penolakan terhadap metafisika oleh kaum positivisme logis khususnya Ayer tidaklah berarti bahwa positivisme itu menolak atau mengingkari keberadaan dunia luar atau dunia yang transenden. Pernyataan mereka bahwa gambaran-gambaran bahasa metafisika itu nirarti bukan berarti pengingkaran secara mutlak. Hal ini dapat dilihat melalui ungkapan Moritz Shlick sebagai berikut:

"Pengingkaran tentang keberadaan dunia luar yang transenden itu berpengertian sama dengan suatu pernyataan metafisis tentang pengakuan keberadaan dunia luar yang transenden. Dengan demikian seorang empiris yang konsisten tidak mengingkari dunia transenden, tetapi menunjukkan bahwa pengingkaran maupun pengakuan kedua-duanya adalah nirarti" (Schlick; 1959).

Jadi kaum positivisme logis atau empirisme logis tidak menyatakan bahwa apa yang dikatakan oleh kaum metafisis itu salah, akan tetatpi apa yang digambarkan mereka tidak menyatakan sesuatu sama sekali. Positivisme logis tidak melawan metafisika, hanya mengatakan bahwa apa yang dikatakan oleh kaum metafisikus tidak dapat dipahami atau tidak menyatakan sesuatu apapun (Poerwowidagdo; 1999).

Menurut positivisme logis, filsafat tidak memiliki suatu wilayah ilmiah tersendiri yang terletak disamping wilayah-wilayah lain sebagai objek ilmu pengetahuan. Filsafat tidak bertugas menyoroti problema-problema ilmu pengetahuan, tetapi bertugas menganalisa ilmu pengetahuan ilmiah. Oleh karena itu filsafat tidak dapat diharapkan untuk memecahkan problema-problema ilmu pengetahuan ilmiah, banyak problema tradisional yang dibicarakan dalam filsafat sebenarnya hanya problema semu saja yang dinampakkan seolah-olah merupakan suatu problema yang amat penting, padahal penjelasan analitis menunjukkan kepalsuan. Atas dasar pemikiran tersebut, kaum positivisme logis menentukan sikap agar tidak terjadi kekacauan, maka analisis terhadap bahasa yang digunakan dalam ilmu pengetahuan dan filsafat merupakan langkah yang 
paling tepat, sehingga pengetahuan ilmiah menemukan jati dirinya sebagai gerakan ilmu pengetahuan yang dibutuhkan dewasa ini.

Metode analisa bahasa yang disampaikan Wittgenstein berhasil membentuk pola pemikiran baru dalam dunia filsafat. Dengan metode analisa bahasa, "tugas filsafat bukannlah membuat pernyataan tentang sesuatu yang khusus" (seperti yang dilakukan para filsuf sebelumnya), melainkan memecahkan persoalan yang timbul akibat ketidakpahaman terhadap bahasa logika (Charlesworth; 1978). Jadi dapat dikatakan bahwa analisa bahasa bersifat kritik terhadap bahasa yang dipergunakan dalam filsafat dan metode ini telah membawa angin segar ke dalam dunia filsafat terutama di Inggris, karena banyak orang menganggap bahasa filsafat terlalu berlebihan dalam mengungkapkan realitas. Begitu banyak ungkapan yang aneh-aneh dalam filsafat, (seperti eksistensi, substansi dan lain-lain), sehingga menimbulkan teka-teki yang membingungkan para pengikut pemikiran filsuf, bahkan mungkin membingungkan pemikiran para filsuf yang menyajikan istilah itu sendiri.

Para filsuf analitik yang mendasarkan pijakannya pada analisa bahasa, bermaksud membersihkan pemakaian bahasa dalam filsafat. Sebab mereka menganggap bahasa filsafat mengandung kekaburan arti (vagueness), bermakna ganda (ambiguity), ketidakterangan (inexplicitness) dan lain-lain. Oleh karena itu perlu disusun suatu kriteria logis yang dapat menentukan apakah suatu ungkapan mengandung makna (meaningfull) atau tidak (meaningless). Dengan demikian menurut Wittgenstein, kita terjebak dalam perangkap filsafat, yakni mencari jawaban terhadap suatu pernyataan yang sesungguhnya tidak dapat diajukan (Wittgenstein; 1983).

Meskipun sulit untuk menentukan corak pemikiran filsafat yang khas pada kurun waktu dewasa ini (abad 20/abad kontemporer), namun banyak ahli filsafat yang menganggap pemikiran filsafat yang bercorak "logosentris" lebih dominan daripada yang lain. Logosentris, artinya para filsuf kebanyakan melihat bahasa sebagai objek terpenting pemikiran mereka (Hamersma; 1986).

Komentar atau kritik yang dapat disampaikan atas penolakan kaum positivisme logis terhadap masalah ketuhanan adalah : pertama, mengenai status prinsip verifikasi itu sendiri merupakan problematik. Proposisi yang mengungkapkan bahwa "hanya pernyataan dan definisi yang dapat diverifikasi saja yang memiliki makna", menimbulkan permasalahan. Pernyataan itu dianggap bermakna apabila dapat dilakukan analisis logis atau observasi empirik. Padahal pernyataan itu sendiri tidak teruji secara ilmiah dengan data inderawi. Apabila sebuah proposisi dijadikan sebagai suatu definisi, maka orang boleh saja menolak definisi yang ditawarkan dengan membuat definisi baru, menurut paradigma yang dianutnya.

Dalam hal ini kelihatannya kaum positivisme logis telah mereduksi makna suatu hal hanya terbatas pada; sesuatu diungkapkan sebagai suatu proposisi dan proposisi itu harus bisa diverifikasi atau difalsifikasi. Padahal dalam kenyataan banyak terdapat hal-hal yang diluar ketentuan itu. Pernyataan tentang keberadaan Tuhan misalnya, mengandung makna bagi para penganut kepercayaan terhadap adanya Tuhan, namun ketika kepercayaan seperti itu harus diungkap dalam bentuk proposisi serta harus dapat diuji secara empiris, maka pernyataan seperti itu dianggap tidak bermakna. Kedua, Kaum Positivisme Logis berlebihan dalam mengagungkan data inderawi. Pengalaman inderawi tidaklah sesederhana yang dibayangkkan. Setiap observasi tidaklah terlepas dari "teori-laden", artinya benar atau salah telah termuat dalam teori itu sendiri. Datum inderawi senantiasa tidak terlepas dari pertimbangan- pertimbangan rasional. Empiris dan rasio senantiasa bekerja sama dan saling melengkapi, bukannya saling meniadakan, sehingga pencapaian data inderawi murni tidaklah mungkin. Ini memberi arti bahwa pernyataan tentang Tuhan hendaknya tidak semata-mata dipahami dari data empiris murni, melainkan juga melibatkan peran rasio.

Ketiga, Positivisme Logis menolak seluruh pernyataan-pernyataan metafisika khususnya pernyataan tentang Tuhan, dan dianggap tidak bermakna, hal ini secara implisit terkandung suatu metafisika di dalam dirinya sendiri. Analisa bahasa juga sebenarnya memasuki wilayah metafisika baru yang harus menerima asumsi-asumsi ontologis secara tidak kritis. Beberapa 
penganut positivisme logis memiliki metafisika fenomenalis, yang di dalamnya seluruh pernyataan direduksi kepada pernyataan empiris. Sadar atau tidak sadar ternyata mereka sepertinya menawarkan pandangan dunia baru dan tidak semata-mata sebagai alat netral untuk menganalisa bahasa.

Positivisme logis semata-mata melihat fakta-fakta yang terukur. Padahal, terdapat realitas yang tidak selamanya dapat diukur, yang justru merupakan hakikat fakta-fakta yang demikian itu. Implikasinya akan memunculkan cara pandang baru dalam model penelitian, yang merupakan hakikat perkembangan ilmu, yang kemudian menjadi pra-syarat mencapai obyektivitas. Perlu menekankan azas komformitas dalam penelitian dengan tidak mengesampingkan orisinalitas. Melalui azas ini, ilmuilmu dapat berkembang secara orisinal; dalam arti penemuan selanjutnya tidak semata-mata tiruan dari penemuan sebelumnya. Ungkapan terakhir yang mungkin dapat penulis katakan adalah bahwa konsep pemikiran positivisme logis apabila dihubungkan dengan persoalan teologi, dengan meminjam kata Louis Leahy adalah atheis.

Sebagai sistem, positivisme menelorkan empirisme dalam epistemologi, determinisme dalaam moral dan agnotisisme dalam metafisika serta atheisme dalam agama. Sebagai kelompok saintis, mereka bermaksud membuat suasana sintesa menyeluruh pengetahuan semata-mata pada taraf objek. Oleh karena itu saintis menjadi contoh utama dari mentalitas yang mencita-citakan suatu reduksi total dari realitas ke dalam kategori objek. Itulah sebabnya mengapa saintisme mengandung pengingkaran segala metafisika, sejauh metafisika menyatakan bahwa dalam kenyataan ditemukan data-data yang berbeda dari hubungan-hubungan ilmiah. Karena prasangka itu saintisme menjadi suatu atheisme (Leahy; 1994).

Thomas Kuhn, berhasil menunjukkan pada dunia bahwa ilmu npengetahuan tidak hanya semata-mata didukung oleh logis-objektif-ahistoris-matematis, tetapi juga oleh faktor subyektivitas kesejarahan, ekonomi, sosial, budaya, bahkan politik praktis manusia itu sendiri (Abdullah; 1996). Hakikat ilmu dalam tubuh positivisme logis bertitik tolak pada dasar perkembangan ilmu-ilmu eksakta, sehingga ilmu-ilmu yang dikembangkan tidak selamanya sejalan dengan perkembangan masyarakat. Obyektivitas yang menjadi pokok perhatian ilmuilmu, justru terketak pada segi tak terungkapnya ilmu-ilmu itu, sehingga mutlak menggunakan subyektivisme yang pada prinsipnya akan mencerminkan obyektivitasnya.

Memang nilai-nilai budaya seperti kebebasan, kejujuran, keadilan, kebenaran, dan lainlain sebagainya yang kesemuanya itu berada dalam tataran filsafati merupakan hal yang begitu abstrak, namun persoalannya akan menjadi sangat konkret apabila pada suatu saat kita merasa kehilangan dan terasing dari nilai-nilai tersebut. Kreativitas, intelektualitas dan istilah-istilah lain dewasa ini termasuk dalam leksikon pembangunan seperti keunggulan kompetitif, siap pakai, link dan mach - kesemuanya itu merupakan strukturisasi dunia lahiriah - akan tetapi labil dan rapuh, serta mustahil akan dapat berfungsi sebagai infra struktur-institusional yang mantap dan mapan bagi gerak lajunya pembaharuan, apabila tidak diimbangi dengan strukturisasi dunia batin rohaniah.

Hal-hal seperti ini terlupakan oleh kaum positivisme logis. Masalah ketuhanan tidak lagi dipersoalkan ada atau tidak adanya Tuhan, melainkan pernyataan-pernyataan tentang Tuhan bermakna atau tidak. Ini berarti terjadi pergeseran kajian filosofis tentang hakikat segala sesuatu menjadi analisa kebahasaan. Memang di satu pihak gejala ini menyadarkan para filsuf agar tidak hanya mengkaji masalah-masalah abstrak dan menghindari mereka dari kerancuan penggunaan istilah atau kalimat. Tetapi dilain pihak perhatian di bidang kefilsafatan menjadi terabaikan, seperti persoalan ketuhanan (teologi), etika dan estetika. Penekanan utama adalah logika dan filsafat bahasa.

\section{Penutup}

Titik tolak Ayer dalam menghapuskan metafisika, disamping menggunakan prinsip 
verifikasi, juga didasarkan pada gagasan Russell tentang aturan-aturan tata bahasa terhadap keniscayaan-keniscayaan logik. Sebagai contoh Ayer menunjukkan kasus yang umum terjadi dalam bahasa Inggris, yakni disaat kita menggambarkan sesuatu melalui penggunaan bentuk tata bahasa dari subjek ke predikat, di situ kita cenderung menganggap bahwa keharusan untuk membuat suatu perbedaan logik antara sesuatu yang digambarkan itu sendiri dengan sifat-sifat pengertiannya.

Pernyataan-pernyataan metafisis menurut positivisme logis merupakan pernyataan yang tidak bermakna, karena pernyataan-pernyataan tersebut tidak dapat diverifikasi. Pernyataan seperti "realitas itu bersifat absolut" atau "realitas itu tidak absolut"; kedua-duanya tidak mungkin diverifikasi, konsekuensinya kedua-duanya merupakan pernyataan yang tidak bermakna. Pernyataan tersebut tidak memiliki kemungkinan untuk dilakukan pembuktian secara empiris. Dari pernyataan di atas memberi pemahaman, bahwa ungkapan-ungkapan metafisis baik yang membenarkan maupun yang menegasikan ungkapan tersebut, kesemuanya omong kosong, sebab tertutup kemungkinan untuk diverifikasi. Ini merupakan penolakan yang sangat radikal kaum positivisme logis terhadap metafisika.

Melalui jalan pikiran Ayer, kita dapat memahami dengan jelas apa sebenarnya tujuan utama yang diinginkannya bersama-sama tokoh-tokoh positivisme logis lainnya. Mereka membentuk kembali bahasa sehari-hari menjadi bahasa yang dibatasi penggunaannya. Melalui teknik analisa bahasa dirumuskan pembatasan-pembatasan yang bersifat operasional. Selain itu mereka mengarahkan filsafat sebagai pendamping ilmu pengetahuan, dalam artian tujuan analisa filsafat adalah mengantar kita ke arah pandangan positivistik mengenai dunia.

Filsafat harus berkembang ke arah logika ilmiah, yakni kegiatan yang memperlihatkan pertalian logis dari hipotesa-hipotesa dan pembatasan simbol-simbol yang terdapat di dalamnya. Dengan demikian jelaslah bahwa alasan utama penghapusan metafisika oleh kaum positivisme logis ini, bukan hanya ungkapan- ungkapan metafisis tidak dapat diverifikasikan secara empirik, bukan pula sekedar tidak dapat dikategorikan sebagai proposisi-proposisi analitik. Tetapi yang jauh lebih penting dari kedua hal ini adalah kaum positivisme logis ini menjadikan filsafat sebagai pendamping utama atau pengantar ke arah bidang ilmiah dalam rangka menyusun pandangan yang positivistik tentang dunia.

Untuk mencapai taraf ini menurut positivisme logis, syarat utamanya adalah menyingkirkan persoalan-persoalan semu (pseudo problems) yang ditimbulkan para ahli metafisika. Menurut Ayer, alasan menentang metafisika itu bukan lantaran sang ahli metafisika itu mencoba menggunakan pengertian dalam suatu bidang yang tidak dapat mendatangkan faedah apapun, melainkan lantaran sang ahli metafisika itu mengajukan kalimat-kalimat yang gagal atau tidak memenuhi syarat untuk dikatakan sebagai kalimat yang benar-benar mengandung makna secara harfiah.

\section{Daftar Pustaka}

Amin Abdullah, M. 1996. Studi Agama: Normativitas atau Historisitas. Pustaka Pelajar. Yogyakarta.

Amstrong, Karen. 1993. A History of God, The 4000-Year Quest of Judaism, Christianity and Islam. Alfred A. Konpt. New York.

Ayer, A., J. 1952. Language, Truth and Logic. Victor Gollancz Ltd. London.

Ayer, A., J. 1984. Problem and Knowledge. Penguin Books. New York.

Bertens K. 1983. Filsafat Barat Abad XX,: Inggris-Jerman. PT. Gramedia. Jakarta. 
Charlesworth, M.J. 1959. Philosophy and Linguistic Analiysis. Duquesne University. Pitsburgh.

Judowibowo-Poerwowidagdo, t.t. 1999. Filsafat Bahasa, Diktat Kuliah pada Universitas Gadjah Mada. Yogyakarta.

Patterson, Charles H. 1971. Western Philosophy, Volume II: Since 1600. Cliff's Notes Inc. Nebraska.

Russell, B. 1974. History of Western Philosophy. George Allen \& Uniwin Paperback. London.

Schlick, Moritz. 1959. Positivism and Realism, dalam Aj. Ayer, (ed.) Logical Positivism, The Free Press,

Stumpf, Samuel Enoch. 1982. Socrates to Sartre: A History of Philosophy. MeGraw-Hill Book Company. New York.

Verhack, C., dan Haryono Imam. 1989. Filsafat Ilmu Pengetahuan, Telaah Atas Cara Kerja IlmuIlmu. Gramedia. Jakarta.

Wittgenstein, Ludwig. 1963. Tractus Logica Philosophicus. Routledge \& Kegan Paul, Ltd. London. 